\title{
Phonetic Transcription Development in KBBI: The Study of Structural Linguistic
}

\author{
$\underline{\text { Sujarno }}{ }^{1}$ \\ ${ }^{1}$ Student in Universitas Negeri Surabaya, Indonesia \\ ${ }^{1}$ Lecturer in SKTIP Muhammadiyah Lumajang, Indonesia \\ Email: Sujarno11@gmail.com
}

Abstract: This research aims to describe the development of The Great Dictionary of the Indonesian Language (abbreviated in English and Indonesian as KBBI) according to phonetic symbol. The data of this qualitative study is the development of KBBI covering phonetic symbol. This research used structural linguistics theory. Specially, the theory includes phonetic symbol. The method of this research is descriptive qualitative research. The data were taken from KBBI I up to KBBI IV which were collected through analysis and documentation from 2013 until 2015. As for the data analysis technique, this study used content technique analysis (reading the data source, comparing, analyzing, interpreting, assigning, and concluding). The result of the study of the development of Kamus Besar Bahasa Indonesia based on phonetic symbol showed no development, because in KBBI I until KBBI IV there is only sound development [é]. Structurally in KBBI I until $K B B I I V$ not showed the realization of phonetic symbolThis study provides suggestions for experts compiling the dictionary content, educational institutions' leaders (school headmasters, Rectors, Head and Director of Institutions), head of libraries, teachers or lecturers, and dictionary users.

Keywords: development of dictionary; phonetics transcription; phonetic; spelling; phonetic symbol.

\section{Introduction}

Lexicography, as a part of linguistic sub-disciplines, cannot be separated from language and linguistic features themselves. Given this reason, it is known that lexicography studies about language itself. The features include phonetics and phonology, morphology, syntax, semantics, as well as pragmatics.

Dictionary, as the product of lexicography, is found in various types of fields. It is widely accepted that each language has its own system, and given all this, credible and trusted dictionary reflects to the language system itself. Language system is constructed from various rules. Among of these rules include three sub-systems: phonological sub-system, grammatical sub-system, and lexicon sub-system. Phonological sub-system deals with how human beings produce sounds of language; the grammatical sub-system concerns with how the words and the sentences are formed and arranged, while the lexicon sub-system talks about vocabularies (Samsuri, 1982: 67; see Lyons 1995: 155).

Social interaction provides insights related to phonological and grammatical sub-systems. Both of the systems are applied and analyzed using scientific tools which are given in formal education. Lexicon sub-system is also found in social interaction even though it is limited due to its need of scientific tool, called dictionary for further enrichment and analysis of vocabulary. Dictionary itself is the product of lexicography which is the practice of compiling, editing, writing, and making of a dictionary.

In actual fact, there are many dictionaries that cannot be categorized as an ideal dictionary. This statement is based on the results of some research which proves that some of dictionaries have not met the requirements to be called as a credible and trusted dictionary. In 


\section{Britain International of Linguistics, Arts and Education (BIoLAE) Journal \\ ISSN: 2685-4813 (Online), 2685-4805 (Print) \\ Vol. 1, No. 2, November 2019, Page: 242-252}

other words, many of those do not follow the standard system of Indonesian language. Even $\mathrm{KBBI}$, which many assumes as the ideal one, needs to be proven of its credibility and reliability. Therefore, it is deemed necessary to conduct a research to prove whether KBBI is an ideal dictionary or not.

\section{Review of Literature}

Many experts have given their definitions of dictionaries as the final product of lexicographic practice. Among those are mentioned below:

a. Dictionary is a reference book which contains a list of words or words combination that includes various aspects of information of their meaning and use in certain language; dictionary, in its tendency, is arranged alphabetically (Kridalaksana, 2010: 86).

b. Dictionary is a book of alphabetically-arranged words from one language containing the meaning of the words, the pronunciation, the spelling, and so on (American Every Dictionary in Chaer 2007: 179).

c. Dictionary is a book containing a list of alphabetically-arranged words from one language; the words are given information about their definitions as well as their equivalents in other languages (Pierre Labrousse in Chaer 2007: 180).

d. In simple terms, Keraf (2007: 44) suggests that dictionary is a book of reference containing an alphabetically-arranged list of words from one language that includes information on how to use those words.

e. Dictionary is [1] a reference book containing alphabetically arranged words and expressions, as well as their meanings, uses, or their tranlations to other language; [2] a book of alphabetically arranged terms and names collection as well as their meaning and uses. (Tim Penyusun Kamus Pusat Pembinaan dan Pengembangan Bahasa, Jakarta: Balai Pustaka 2001).

According to those definitions, it is concluded that:

a. Dictionary is a reference book containing a list of words and word combination from one language.

b. The words are alphabetically arranged.

c. There are given information about the meaning and the uses.

d. As well as given information about the pronunciation, spelling, and various other things.

e. The words are translated to other languages, hence there are monolingual dictiories and billingual dictionaries.

f. In addition, there is also a specialized dictionary containing registers from specific fields of studies.

However, those definitions still do not provide enough requirements for the concept of an ideal dictionary. To be the ideal one, a dictionary also needs to include syllabification, the information of words origin, the information of which fields the words are appropriate to used, the standard forms, the information of whether the words are archaic or classics, the areas of words use, and other various information. If those features are found in a dictionary, then it fulfills the requirements of an ideal dictionary.

The body is the most important parts of the dictionary. It includes a list of alphabetically arranged words and their additional features as mentioned before, Kamus Umum Bahasa Indonesia, for example, uses the Latin alphabet, namely: a, b, c, d, e, f, g, h, i, j, k, 1, m, n, o, p, q, r, s, t, u, v, w, x, y, z. Given to this rule, for some of double phonemes are categorized to the initial letters of the words, for examples: ny, ng are categorized in N-letter group; kh belongs to K-letter group. From the body of a dictionary, we are given the numbers of information 
including standard spelling, syllables, accents, capitalization system, pronunciation, word class, etymology, definitions, synonyms, and derivative forms (Keraf, 2007: 46).

The practice of lexicography has proven that there is no an ideal dictionary providing a complete meaning of a word. It happens because language changes over time, along with sociocultural changes in society. As the result, there are lots of new words created, and there are words becoming archaic even disappear, which then affects the whole parts of dictionary; the dictionary becomes incomplete because of those words. The changes of meaning also happen through the years, which mean that the dictionary becomes semantically less credible. Due to these phenomena, revision is conducted every three or five years. Theoretically, once a dictionary is published then revision practice is started. (Chaer, 2007: 206-210).

From all of this, it can be assumed that an ideal dictionary contains, at least some features mentioned below:

a. Complete features of the word system

b. Complete, Precise, and Clear Gloss

c. Pronunciation and Spelling Information

d. World Class Information

e. Variety and Variation of Words

f. Etymology

g. The fields of words usage

h. The area of words usage

i. Social class of the words

j. Standardized Words Information

Linguistics is a field of study consisting of several sub-fields. One of the linguistic subfields is phonology. Among those sub-fields, some of them are used in dictionary, for examples: phonetic spelling and its transcription. This important part of dictionary is called as Phonetic Symbol.

\section{Discussion}

\subsection{Analysis and Discussion of Research Results}

In Phonology, there are three systems of writing and spelling. Those three are phonetic spelling for phonetic writing, phonemic spelling for phonemic writing, and other orthography systems. One of those systems is phonetic spelling for phonetic writing. (Chaer, 2007: 109). Phonetic writing is a writing system for phonetic spelling. The system includes a set of symbols derived from the pronunciation of each letter in alphabet. There are three important points need to be considered in phonetics. Those are:

Different sound is written with different symbol.

One sound has one particular symbol.

Phonetic writing is enclosed by square brackets ([...])

Sound writing in the form of phonetic symbols is known as phonetic transcription. Phonetic symbol is a group of symbols created by International Phonetic Association (IPA), the representative organization for phoneticians. It was established in 19th century, and has played important role in providing new methodology in learning spoken language.

The symbolic system created by the association is known as International Phonetic Alphabet (IPA). The system consists of a set of symbols based on Latin alphabet, which was created to give particular symbol to each sound. The system was created because the number of sounds is greater than the number of Latin alphabet itself. In order to solve this problem, the 
association modified the forms of alphabets to differ one to another. In modifying those forms, an alphabet which has many way of pronunciation, is written with different symbol, but the form of the symbols is still on the basic form of the modified alphabet. The difference can be seen from the use of diacritics.

Phonetic symbols are symbols of linguistic sounds created from how words are pronounced. In Phonetics, different sound must be symbolized by different symbol. It is stated that one sound only has one phonetic symbol. The differences of sound in one symbol are distinguished by diacritic marks placed at the top or bottom of the symbol. (Muslich, 2008: 42). Muslich, also said that the phonetics can be used for all languages in the world. The sound symbol was established by The International Phonetic Association (IPA) or the association of language teachers established at the end of the 19th century. The system is commonly called International Phonetic Alphabet (IPA).

The problem of the phonetic symbol development in this study is focused on the data entry contained in the KBBI. Based on the data, it is stated that not all entries in KBBI are given their phonetic symbol. Among the examples of phonetic symbol found in KBBI can be seen in table B.1 below.

Table 1. Examples of Phonetic Transcription Data Development

\begin{tabular}{|c|c|c|c|c|c|}
\hline CODE & KBBI I & KBBI II & KBBI III & KBBI IV & \begin{tabular}{|c|} 
ADDITIONAL \\
INFORMATION \\
\end{tabular} \\
\hline TFM0001 & $\begin{array}{c}{ }^{1} \mathbf{M}, \mathbf{m} \angle \text { ém } / n \\
\text { huruf ketiga } \\
\text { belas abjad } \\
\text { Indonesia }\end{array}$ & $\begin{array}{l}{ }^{1} \mathbf{M}, \mathbf{m} \angle \text { Lém/ } \\
n \text { huruf } \\
\text { ketiga } \\
\text { belas } \\
\text { abjad } \\
\text { Indonesia } \\
{ }^{2} \mathbf{M} / \text { ém/ } n \\
k p \text { Masehi }\end{array}$ & $\begin{array}{l}{ }^{1} \mathbf{M}, \mathbf{m} \angle \text { Lém/ } \\
n \text { huruf } \\
\text { ketiga } \\
\text { belas } \\
\text { abjad } \\
\text { Indonesia } \\
\\
{ }^{2} \mathbf{M} / \text { ém/ } n \\
\text { kp Masehi }\end{array}$ & $\begin{array}{l}{ }^{1} \mathbf{M}, \mathbf{m} \text { Lém/ } \\
n \text { huruf } \\
\text { ketiga } \\
\text { belas } \\
\text { abjad } \\
\text { Indonesia } \\
\\
{ }^{2} \mathbf{M} / \text { ém/ } n \\
\text { kp Masehi }\end{array}$ & $\begin{array}{l}\text { From KBBI I } \\
\text { to KBBI IV, } \\
\text { phonetic } \\
\text { symbol is given } \\
\text { only to the } \\
\text { sound [é]. In } \\
\text { other words, } \\
\text { there is no } \\
\text { development in } \\
\text { phonetic } \\
\text { transcription in } \\
\text { KBBI. }\end{array}$ \\
\hline TFM0003 & $\begin{array}{l}\text { maesenas } \\
\text { /maésénas/ } \\
n \text { orang kaya } \\
\text { pendukung } \\
\text { kebudayaan; } \\
\text { pelindung } \\
\text { seni dan } \\
\text { kalangan } \\
\text { seniman: } \\
\text { kita } \\
\text { memerlukan -- } \\
\text { untuk } \\
\text { menggairabka } \\
n \text { kegiatan seni }\end{array}$ & $\begin{array}{l}\text { ma.e.se.nas } \\
\text { /maésénas } \\
L n \text { orang } \\
\text { kaya } \\
\text { pendukun } \\
\mathrm{g} \\
\text { kebudayaa } \\
\mathrm{n} ; \\
\text { pelindung } \\
\text { seni dan } \\
\text { kalangan } \\
\text { seniman: } \\
\text { kita } \\
\text { memerlukan } \\
-- \\
\text { menggairabk } \\
\text { an kegiatan } \\
\text { seni }\end{array}$ & $\begin{array}{l}\text { ma.e.se.nas } \\
\text { /maésénas } \\
L n \text { orang } \\
\text { kaya } \\
\text { pendukun } \\
\mathrm{g} \\
\text { kebudayaa } \\
\mathrm{n} ; \\
\text { pelindung } \\
\text { seni dan } \\
\text { kalangan } \\
\text { seniman: } \\
\text { kita } \\
\text { memerlukan } \\
-- \\
\text { menggairabk } \\
\text { an kegiatan } \\
\text { seni }\end{array}$ & $\begin{array}{l}\text { ma.e.se.nas } \\
\text { /maésénas } \\
L n \text { orang } \\
\text { kaya } \\
\text { pendukun } \\
\mathrm{g} \\
\text { kebudayaa } \\
\mathrm{n} ; \\
\text { pelindung } \\
\text { seni dan } \\
\text { kalangan } \\
\text { seniman: } \\
\text { kita } \\
\text { memerlukan } \\
-- \\
\text { menggairabk } \\
\text { an kegiatan } \\
\text { seni }\end{array}$ & \\
\hline
\end{tabular}


Britain International of Linguistics, Arts and Education (BIoLAE) Journal

ISSN: 2685-4813 (Online), 2685-4805 (Print)

Vol. 1, No. 2, November 2019, Page: 242-252

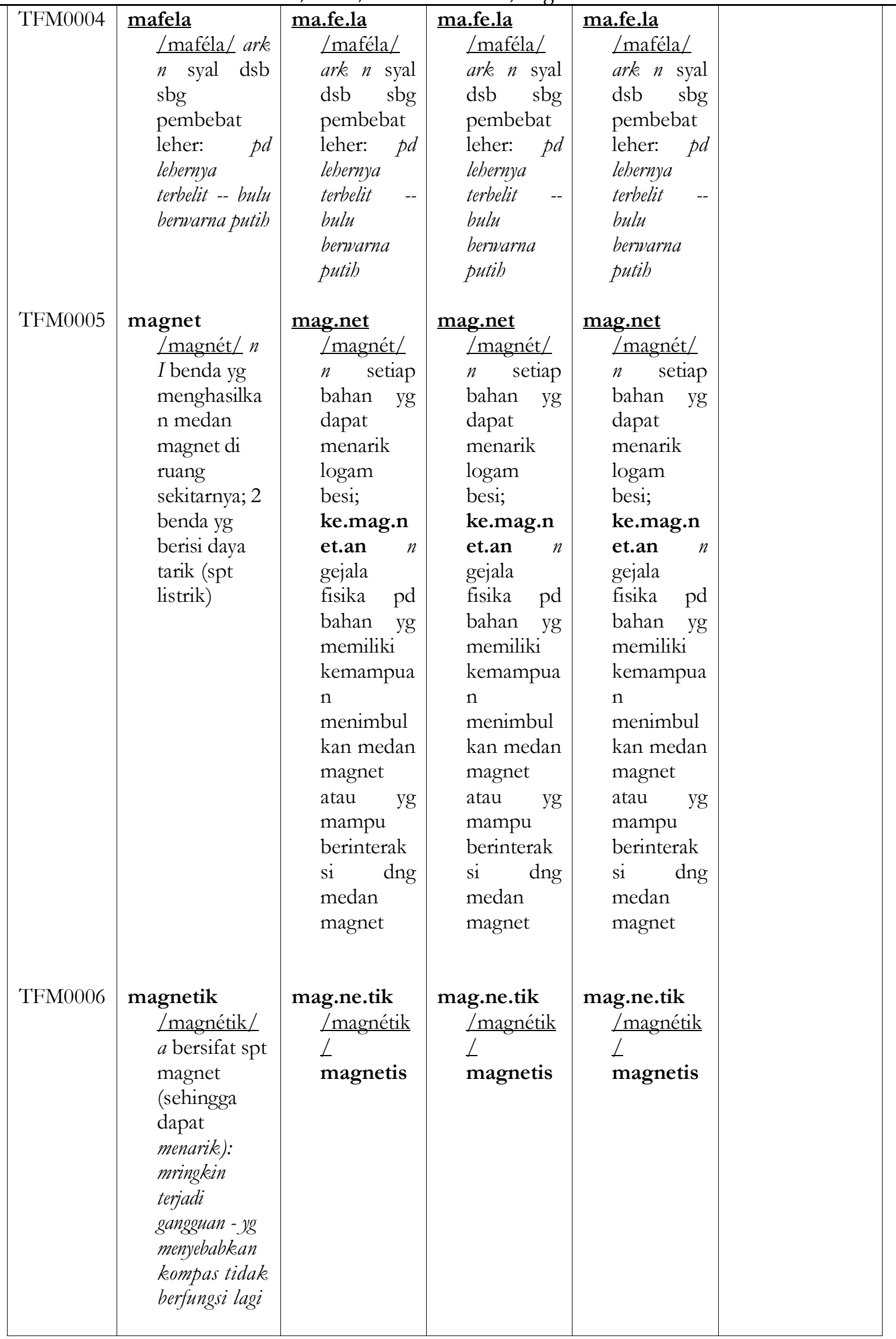


We can see from data mentioned in table B.1 that not all entries have complete phonetic symbols. Based on the theory of structural linguistics, different sound should have different symbol. Given by this theory, all entries in the four versions of KBBI need to have complete phonetic symbols because each entry is composed of a series of sounds. Among the series of sounds, of course, there are different sounds of pronunciation.

As mentioned above, every different sound is symbolized by different symbol. However, not all of the entries have the phonetic symbol. The absence of the phonetic symbol is found in KBBI I, KBBI II, KBBI III, or KBBI IV.

Based on the data in table B.1, the development of phonetic transcription is focused only on the sound [é]. In other words, there is no progress in the completeness of the phonetic symbol in KBBI. There is only a little amount of phonetic transcription development following KBBI I. Furthermore, there is also the omission of some phonetic symbols that occurs in the newer version of KBBI.

In its development, some of the entries mentioned above have been completed by phonetic symbols. However, it is focused only on the sound [é], while other sound symbols are not yet. Some entries that have been completed with the phonetic symbols can be seen in table B. 2 below.

Table 2. Examples of Entries Completed with Phonetic Symbols

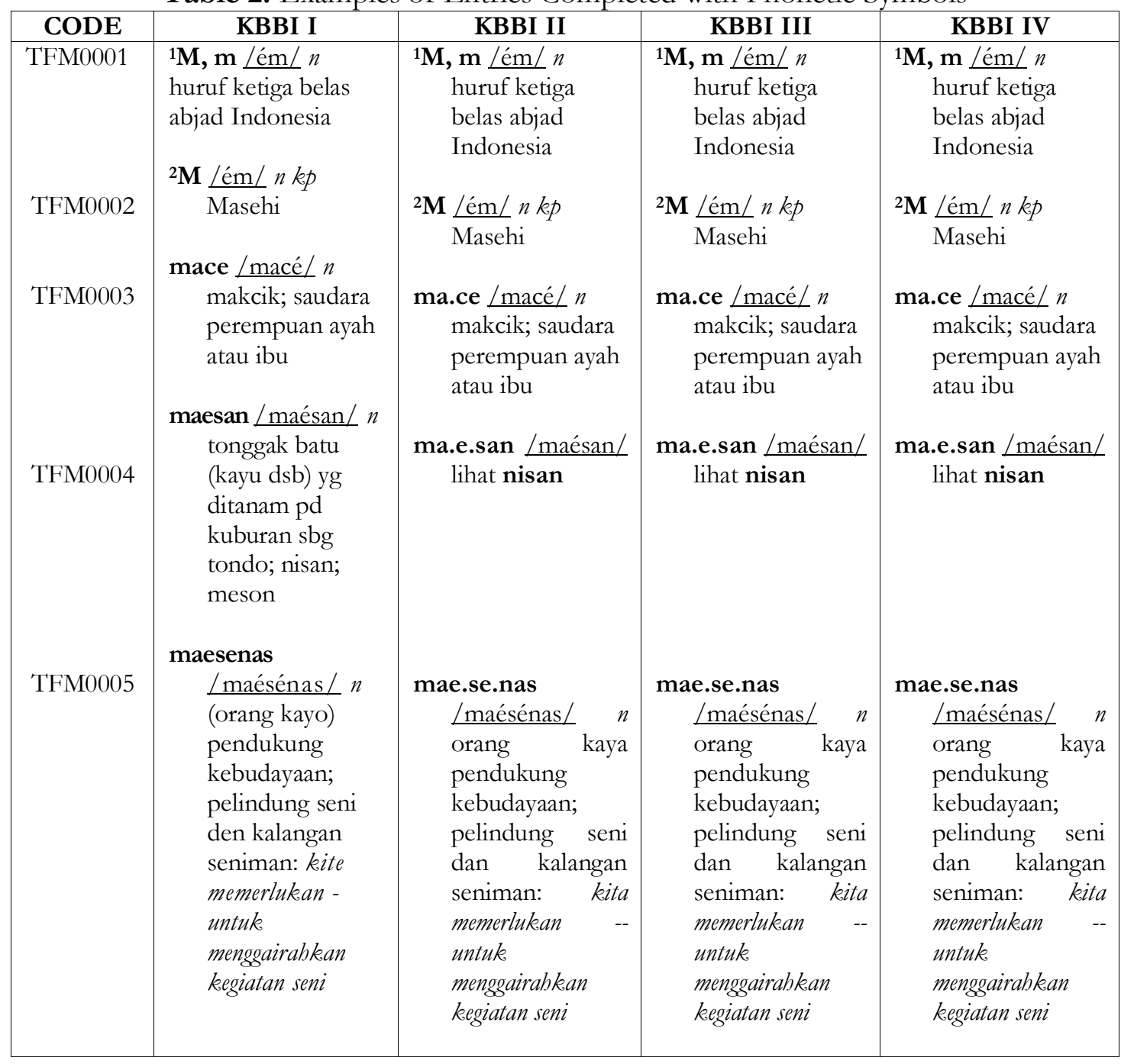


As stated in Structural Linguistics, the phonetic symbol is enclosed in square brackets ([...]). However, it is not applied in KBBI. The phonetic transcription is enclosed by slash symbol $(/ \ldots /)$ which is known as for phonemic symbol. Thus, it is more appropriate to call the transcription as phonemic transcription rather than phonetic transcription. The examples of the data can be seen from entries containing [é] sound.

As seen in table B.2, phonetic symbol is only applied to sound / é / symbol: mahadewa, magnetir, magnet, and the other entries. From the data, we can conclude there is no development related to the completeness of the phonetic symbol in KBBI. It is based on a reason that KBBI I has completed all of phonetic transcription, hence there is no new additions to the newer ones: KBBI II, KBBI III, and KBBI IV, which actually only focuses on symbol [é] only. As we know, there are some sounds with the same orthographic symbol but pronounced differently. Due to this reason, the phonetic symbol must be different. For sounds: [i, I, e, $\varepsilon$, ə, o, $\mathrm{O}, \mathrm{u}, \mathrm{U}]$ consider the following table.

Table 3. Phonetic Symbol Transcription

\begin{tabular}{|c|c|c|}
\hline Phonetic Symbol & Latin Alphabet & Example \\
\hline [i] & Similar with letter i & [bi+sa] 'bisa', [sa+dis] 'sadis \\
\hline T] & Similar with letter i with tilde & [sopIr] 'sopir', [sIk'+sa] 'siksa' \\
\hline [e] & Similar with letter e & [sa+te] 'sate', [so+re] 'sore \\
\hline$[\varepsilon]$ & Similar with letter capital e & [ən+d ع?] 'pendek', [r $\varepsilon+\mathrm{m} \varepsilon \mathrm{c}]$ 'remeh' \\
\hline [ə] & Similar with letter inverted e & {$[\mathrm{k} ə+\mathrm{l} ə+\mathrm{la}+\mathrm{war}]$ 'kelelawar' } \\
\hline$[\mathrm{u}]$ & Similar with letter u & [bu+ku] 'buku', [mu+tu] 'mutu' \\
\hline [U] & Similar with letter capital u & [ba+tU?] 'batuk', [um+bUl] 'umbul' \\
\hline [o] & Similar with letter o & [so +to] 'soto', [ka+do] 'kado' \\
\hline [O] & Similar with letter capital o & [?Oñ+cOm] 'oncom', [bO+rOs] 'boros \\
\hline
\end{tabular}
table.

Looking at the phonetic symbols in KBBI, the development can be seen the following

a. The Development of Phonetic Symbol in KBBI I to KBBI II

Table 4. The Development of phonetic symbol on KBBI I to KBBI II

\begin{tabular}{|c|c|c|c|}
\hline CODE & KBBI I & KBBI II & $\begin{array}{l}\text { ADDITIONAL } \\
\text { INFORMATION. }\end{array}$ \\
\hline TFM0001 & $\begin{array}{l}{ }^{1} \mathbf{M}, \mathbf{m} / \text { /ém } / n \text { huruf } \\
\text { ketiga belas abjad } \\
\text { Indonesia }\end{array}$ & $\begin{array}{l}1 \mathbf{M}, \mathbf{m} / \text { ém/ } n \text { huruf } \\
\text { ketiga belas abjad } \\
\text { Indonesia }\end{array}$ & $\begin{array}{l}\text { There is no development of } \\
\text { phonetic transcription from } \\
\text { KBBI I to KBBI II. The } \\
\text { phonetic sumbol used in }\end{array}$ \\
\hline TFM0002 & ${ }^{2} \mathbf{M} /$ ém/ n kp Masehi & ${ }^{2} \mathbf{M} /$ ém/ $n$ kp Masehi & $\begin{array}{l}\text { KBBI I is the same as the } \\
\text { phonetic symbol used in }\end{array}$ \\
\hline TFM0003 & $\begin{array}{l}\text { mace / macé/ } n \text { makcik; } \\
\text { saudara perempuan } \\
\text { ayah atau ibu }\end{array}$ & $\begin{array}{l}\text { mace /macé/ } n \text { makcik; } \\
\text { saudara perempuan } \\
\text { ayah atau ibu }\end{array}$ & KBBI II. \\
\hline TFM0004 & $\begin{array}{l}\text { maesan / maésan/ } n \\
\text { tonggak batu (kayu } \\
\text { dsb) yg ditanam pd } \\
\text { kuburan sbg tondo; } \\
\text { nisan; meson }\end{array}$ & $\begin{array}{l}\text { maesan / maésan/ } n \\
\text { tonggak batu (kayu } \\
\text { dsb) yg ditanam pd } \\
\text { kuburan sbg tondo; } \\
\text { nisan; meson }\end{array}$ & \\
\hline TFM0005 & $\begin{array}{l}\text { maesenas / maésénas / } \\
n \text { (orang kayo) }\end{array}$ & $\begin{array}{c}\text { maesenas / maésénas / } \\
n \text { (orang kayo) }\end{array}$ & \\
\hline
\end{tabular}




\begin{tabular}{|c|c|c|}
\hline TFM0006 & $\begin{array}{l}\text { pendukung } \\
\text { kebudayaan; } \\
\text { pelindung seni den } \\
\text { kalangan seniman: } \\
\text { kite memerlukan - } \\
\text { untuk menggairablean } \\
\text { kegiatan seni } \\
\text { mafela /maféla/ } n \text { syal } \\
\text { dsb sbg pembebat } \\
\text { leher: pd lehernya } \\
\text { terbelit -- bulu berwarna } \\
\text { putih }\end{array}$ & $\begin{array}{l}\text { pendukung } \\
\text { kebudayaan; } \\
\text { pelindung seni den } \\
\text { kalangan seniman: } \\
\text { kite memerlukan - } \\
\text { untuk menggairabkan } \\
\text { kegiatan seni } \\
\text { mafela /maféla/ } n \text { syal } \\
\text { dsb sbg pembebat } \\
\text { leher: pd lehernya } \\
\text { terbelit -- bulu berwarna } \\
\text { putib }\end{array}$ \\
\hline
\end{tabular}

Based on the data, it can be stated that there is no phonetic symbol development occurred from KBBI I to KBBI II. There are no differences between KBBI I and KBBI II. Both use the same phonetic symbol which is /é/ and double slash.

b. The Development of Phonetic Symbol in KBBI II to KBBI III

Table 5. The Development of phonetic symbol on KBBI II to KBBI III

\begin{tabular}{|c|c|c|c|}
\hline CODE & KBBI II & KBBI III & $\begin{array}{l}\text { ADDITIONAL } \\
\text { INFORMATION }\end{array}$ \\
\hline TFM0001 & $\begin{array}{c}{ }^{\mathbf{1}} \mathbf{M}, \mathbf{m} \text { /ém/ } n \text { huruf ketiga } \\
\text { belas abjad Indonesia }\end{array}$ & $\begin{array}{l}{ }^{1} \mathbf{M}, \mathbf{m} / \text { ém / } n \text { huruf } \\
\text { ketiga belas abjad } \\
\text { Indonesia }\end{array}$ & $\begin{array}{l}\text { There is no development of } \\
\text { phonetic transcription from } \\
\text { KBBI II to KBBI III. The } \\
\text { phonetic svmbol used in KBBI }\end{array}$ \\
\hline & ${ }^{2} \mathbf{M}$ /ém/ n kp Masehi & & $\begin{array}{l}\text { II is the same as the phonetic } \\
\text { symbol used in KBBI III. }\end{array}$ \\
\hline TFM0003 & $\begin{array}{l}\text { mace / macé/ } n \text { makcik; } \\
\text { saudara perempuan } \\
\text { ayah atau ibu }\end{array}$ & $\begin{array}{l}\text { mace / macé/ } n \text { makcik; } \\
\text { saudara perempuan } \\
\text { ayah atau ibu }\end{array}$ & \\
\hline TFM0004 & $\begin{array}{l}\text { maesan / maésan/ } n \\
\text { tonggak batu (kayu dsb) } \\
\text { yg ditanam pd kuburan } \\
\text { sbg tondo; nisan; meson }\end{array}$ & $\begin{array}{l}\text { maesan / maésan/ } n \\
\text { tonggak batu (kayu dsb) } \\
\text { yg ditanam pd kuburan } \\
\text { sbg tondo; nisan; } \\
\text { meson }\end{array}$ & \\
\hline TFM0005 & $\begin{array}{l}\text { maesenas / maésénas / } n \\
\text { (orang kayo) pendukung } \\
\text { kebudayaan; pelindung } \\
\text { seni den kalangan } \\
\text { seniman: kite } \\
\text { memerlukan - untuk } \\
\text { menggairabkan kegiatan } \\
\text { seni }\end{array}$ & $\begin{array}{l}\text { maesenas / maésénas / n } \\
\text { (orang kayo) } \\
\text { pendukung } \\
\text { kebudayaan; pelindung } \\
\text { seni den kalangan } \\
\text { seniman: kite } \\
\text { memerlukan - untuk } \\
\text { menggairabkan kegiatan } \\
\text { seni }\end{array}$ & \\
\hline TFM0006 & $\begin{array}{l}\text { mafela / maféla/ } n \text { syal dsb } \\
\text { sbg pembebat leher: } p d \\
\text { lehernya terbelit -- bulu } \\
\text { berwarna putib }\end{array}$ & $\begin{array}{c}\text { mafela /maféla/ } n \text { syal } \\
\text { dsb sbg pembebat } \\
\text { leher: pd lehernya terbelit - } \\
\text { - bulu berwarna putih }\end{array}$ & \\
\hline
\end{tabular}


There is no development of phonetic symbols occurred from KBBI II to KBBI III. There are no differences between the two editions. Both use the same phonetic symbol, which is / é / and double slash.

c. The Development of Phonetic Symbol in KBBI III to KBBI IV

Table 6. The Development of phonetic symbol on KBBI III to KBBI IV

\begin{tabular}{|c|c|c|c|}
\hline CODE & KBBI III & KBBI IV & $\begin{array}{l}\text { ADDITIONAL } \\
\text { INFORMATION }\end{array}$ \\
\hline TFM0001 & $\begin{array}{l}{ }^{1} \mathbf{M}, \mathbf{m} \text { /ém/ } n \text { huruf } \\
\text { ketiga belas abjad } \\
\text { Indonesia }\end{array}$ & $\begin{array}{l}{ }^{1} \mathbf{M}, \mathbf{m} / \text { ém / } n \text { huruf } \\
\text { ketiga belas abjad } \\
\text { Indonesia }\end{array}$ & $\begin{array}{l}\text { There is no development of } \\
\text { phonetic transcription from } \\
\text { KBBI III to KBBI IV. The }\end{array}$ \\
\hline TFM0002 & ${ }^{2} \mathbf{M}$ /ém/ n kp Masehi & ${ }^{2} \mathbf{M}$ /ém/ $n$ kp Masehi & $\begin{array}{l}\text { KBBI III is the same as the } \\
\text { phonetic symbol used in }\end{array}$ \\
\hline TFM0003 & $\begin{array}{l}\text { mace / macé/ } n \text { makcik; } \\
\text { saudara perempuan } \\
\text { ayah atau ibu }\end{array}$ & $\begin{array}{l}\text { mace / macé/ } n \text { makcik; } \\
\text { saudara perempuan } \\
\text { ayah atau ibu }\end{array}$ & KBBI IV. \\
\hline TFM0004 & $\begin{array}{l}\text { maesan / maésan/ } n \\
\text { tonggak batu (kayu } \\
\text { dsb) yg ditanam pd } \\
\text { kuburan sbg tondo; } \\
\text { nisan; meson }\end{array}$ & $\begin{array}{l}\text { maesan / maésan/ } n \\
\text { tonggak batu (kayu } \\
\text { dsb) yg ditanam pd } \\
\text { kuburan sbg tondo; } \\
\text { nisan; meson }\end{array}$ & \\
\hline TFM0005 & $\begin{array}{l}\text { maesenas / maésénas / } \\
n \text { (orang kayo) } \\
\text { pendukung } \\
\text { kebudayaan; } \\
\text { pelindung seni den } \\
\text { kalangan seniman: } \\
\text { kite memerlukan - } \\
\text { untuk menggairabkan } \\
\text { kegiatan seni }\end{array}$ & $\begin{array}{l}\text { maesenas / maésénas / } \\
n \text { (orang kayo) } \\
\text { pendukung } \\
\text { kebudayaan; } \\
\text { pelindung seni den } \\
\text { kalangan seniman: } \\
\text { kite memerlukan - } \\
\text { untuk menggairabkan } \\
\text { kegiatan seni }\end{array}$ & \\
\hline TFM0006 & $\begin{array}{l}\text { mafela / maféla/ } n \text { syal } \\
\text { dsb sbg pembebat } \\
\text { leher: pd lehernya } \\
\text { terbelit -- bulu berwarna } \\
\text { putih }\end{array}$ & $\begin{array}{l}\text { mafela /maféla/ } n \text { syal } \\
\text { dsb sbg pembebat } \\
\text { leher: pd lehernya } \\
\text { terbelit -- bulu berwarna } \\
\text { putib }\end{array}$ & \\
\hline
\end{tabular}

There is no change of phonetic symbols occurred from KBBI III to KBBI IV. They use the same phonetic symbol, which is / é / and the appropriate phonetic symbol -square brackets is still not used in the latest edition. Looking at all the tables above, it can be concluded that (consider the following table):

Table 7. The Development of KBBI's Phonetic Transcription

\begin{tabular}{|l|l|l|l|l|}
\hline \multicolumn{1}{|c|}{ KBBI I } & \multicolumn{1}{c|}{ KBBI II } & \multicolumn{1}{c|}{ KBBI III } & KBBI IV & \multicolumn{1}{c|}{$\begin{array}{c}\text { ADDITIONAL } \\
\text { INFROMATION }\end{array}$} \\
\hline $\begin{array}{l}\text { The phonetic } \\
\text { transcription } \\
\text { has been added. }\end{array}$ & $\begin{array}{l}\text { The phonetic } \\
\text { transcription } \\
\text { has been added. }\end{array}$ & $\begin{array}{l}\text { The phonetic } \\
\text { transcription } \\
\text { has been added. }\end{array}$ & $\begin{array}{l}\text { The phonetic } \\
\text { transcription } \\
\text { has been added. }\end{array}$ & $\begin{array}{l}\text { There is no new } \\
\text { phonetic symbol } \\
\text { addition in phonetic }\end{array}$ \\
\hline
\end{tabular}


Vol. 1, No. 2, November 2019, Page: 242-252

\begin{tabular}{|l|l|l|l|l|}
\hline However, the & However, the & However, the & However, the & transcription from \\
transcription is & transcription is & transcription is & transcription is \\
added only for & added only for & KBdded only for & added only for & All editions are the \\
entries that & entries that & entries that & entries that \\
contain sounds & contain sounds & contain sounds & contain sounds \\
[é]. & [é]. & [é]. & \\
\hline
\end{tabular}

\section{Conclusion}

a. Phonetic symbol is known as phonetic transcription. The writing is known as the phonetic spelling.

b. There are 3 things to consider regarding phonetic transcription. These three things are as stated below.

a) Different sound must be written with a different symbol.

b) Each sound must be symbolized by one symbol.

c) The phonetic transcription is enclosed by square brackets ([...])

c. KBBI I to KBBI IV provides phonetic transcription for the readers.

However, it is limited only to the sound [é]. The newer editions have not been undergoing development of phonetic transcription.

\section{References}

Alwi, H. (1993). Tata Bahasa Baku Bahasa Indonesia. Jakarta: Balai Pustaka.

Ayatrohaedi. (1993). "Rucita dalam Kamus Besar Bahasa Indonesia" dalam Djoko Kentjono

(Ed.) Tata Bahasa Baku Bahasa Indonesia dan Kamus Besar Bahasa Indonesia: 84 - 90.

Depok: FS-UI.

Bloomfield, L. (1973). language. London: George Allen \& Unwin LTD.

Chaer, A. (2007). Leksikologi dan Leksikografi Indonesia. Jakarta: Rineka Cipta.

Chaer, A. (2007). Linguistik Umum. Jakarta: Rineka Cipta.

Chaer, A. (2009). Fonologi bahasa Indonesia. Jakarta: Rineka Cipta.

Chaer, A. (2010). Telaah Bibliografi Kebahasaan Bahasa Indonesia/Melayu. Jakarta: Rineka Cipta.

Echols, J.H. \& Shadily, H. (1988). Kamus Indonesia - Inggris. Jakarta: Gramedia.

Echols, J.H. \& Shadily, H. (2003). Kamus Inggris - Indonesia. Jakarta: Gramedia.

Keraf, G. (1988). Introduction to Word Formation and Word Classes in Indonesian. Depok: Pusat Leksikologi dan Leksikografi Universitas Indonesia.

Keraf, G. (2004). Komposisi. Ende-Flores: Nusa Indah.

Keraf, G. (2007). Diksi dan Gaya Bahasa. Jakarta: Gramedia.

Keraf, G. (2010). Kamus Linguistik. Jakarta: Gramedia.

Lyons, J. (1995). Pengantar Teori Linguistik Terjemahan I. Soetikno. Jakarta: Gramedia.

Mahsun. (2007). Metode Penelitian Bahasa: Tahapan, Strategi, Metode, dan Tekniknya. Jakarta:

Raja Grafindo Persada.

Muhadjir. (1993). "Kamus Besar dan Tata Bahasa Baku Bahasa Indonesia" dalam Djoko

Kentjono (Ed.) Tata Bahasa Baku Bahasa Indonesia dan Kamus Besar Bahasa Indonesia:

1 -13. Depok: FS-UI.

Muslich, M. (2009). Fonologi Bahasa Indonesia. Surabaya: Bumi Aksara.Press.

P3BI. (2010). Kamus Besar Bahasa Indonesia. Jakarta: Balai Pustaka.

Parmin, J.dkk.(2011). Menulis Ilmiah: Buku Ajar MPK Bahasa Indonesia. Surabaya: Unesa University Press.

Poerwadarminta, W.J.S. (2000). Kamus Umum Bahasa Indonesia. Jakarta: Balai Pustaka. 
Ramlan, M. (1990). Ilmu Bahasa Indonesia: Morfologi. Yogyakarta: Gajah Mada University Press.

Robins, R.H. (1992). Linguistik Umum Terjemahan Soenarjati Adinegara. Yogyakarta: Kanisius. Santosa, P. (2014). Materi dan Pembelajaran Bahasa Indonesia. Jakarta: Universitas Terbuka.

Saussure, F.D. (1993). Pengantar Linguistik Umum. Terjemahan Rahayu S Hidayat. Yogyakarta: Gadjah Mada University Press.

Suparno. (2002). Dasar-Dasar Linguistik Umum. Yogyakarta: Tiara Wacana.

Verhaar, J.W.M. (1999). Asasa-asas Linguistik Umum. Yogyakarta: Gajah Mada University Press. 